\title{
Шановні колеги!
}

Стоматологічна спільнота України в жовтні 2021 року мала нагоду зібратися на 6-й Національний український стоматологічний конгрес 3 міжнародною участю «нноваційні технології в стоматології». У рамках конгресу відбулося святкування 65-ї річниці професійного об'єднання лікарів-стоматологів України, а саме Республіканського наукового товариства стоматологів УРСР та Асоціації стоматологів України.

Національний український стоматологічний конгрес було організовано 3 метою широкого висвітлення наукових і практичних досягнень української наукової стоматологічної школи. Свої наукові здобутки та практичні розробки подали науковці, науково-педагогічні працівники стоматологічних факультетів закладів вищої освіти МОЗ України, організатори охорони здоров'я та практикуючі лікарістоматологи.

Матеріали конгресу ви знайдете на шпальтах цього номера журналу «Oral and General Health» - це статті та тези молодих вчених і лікарів-стоматологів.

Окрім цього, на сторінках журналу подані цікаві наукові та історичні статті, аналітична інформація щодо стоматологічної допомоги в Україні. До вашої уваги пропонуємо юридичні поради для лікарів щодо організації приватних стоматологіч-

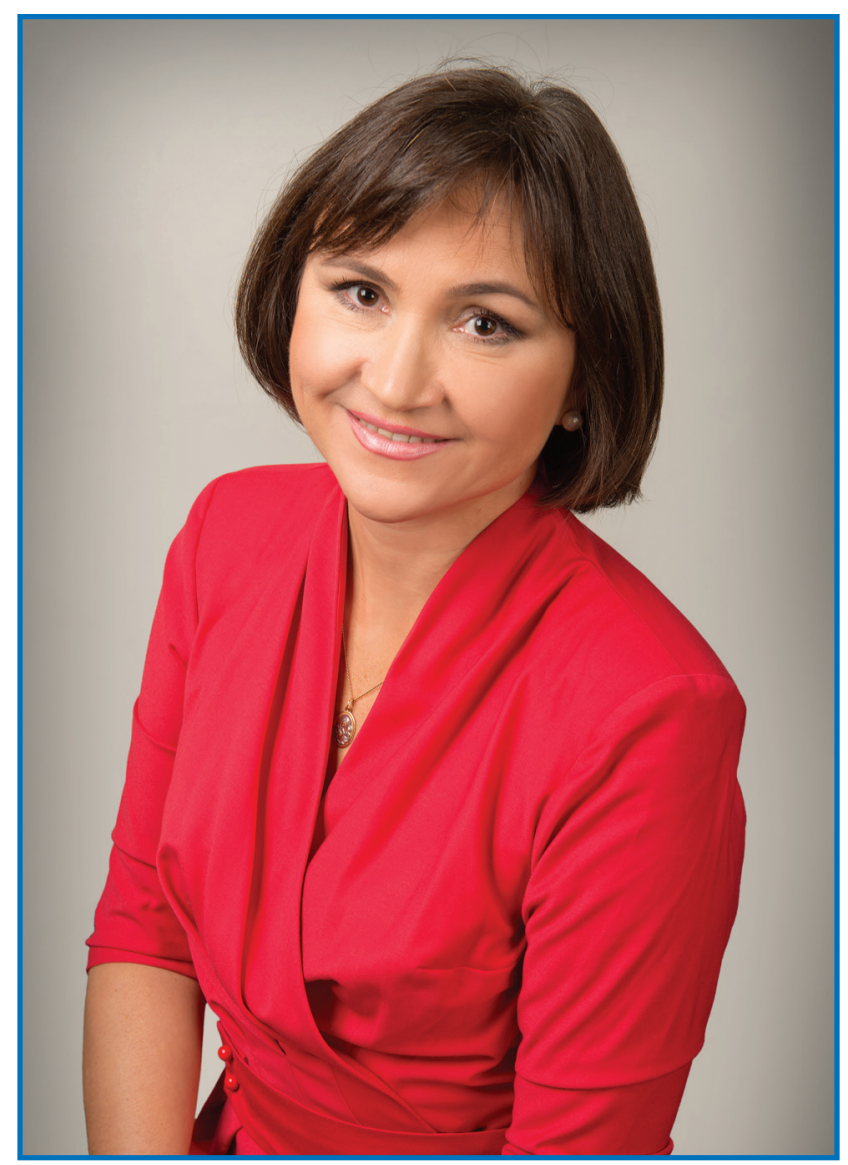

них закладів та правових аспектів діяльності.

Редакційна рада журналу запрошує лікарів-стоматологів, лікарів загальної практики, науковців до співпраці у підготовці якісного контенту журналу!

З повагою, професор І.П. Мазур 